\title{
Analisis Pengaruh Karakteristik Audit dan Karakteristik Perusahaan Terhadap Pergantian Kantor Akuntan Publik pada Perusahaan yang Terdaftar di Bursa Efek Indonesia
}

\author{
Budi Chandra \\ Universitas Internasional Batam \\ Budi.chandra@uib.ac.id \\ Jessy Christianti \\ Universitas Internasional Batam \\ Jessychristianti@rocketmail.com
}

\begin{abstract}
Abstrak
Studi ini bertujuan untuk mengkaji pengaruh dari karakteristik audit dan karakteristik perusahaan terhadap pergantian Kantor Akuntan Publik di Indonesia. Karakteristik audit terdiri atas opini audit, keterlambatan audit, dan reputasi KAP. Karakteristik perusahaan terdiri atas ukuran perusahaan, kesulitan keuangan, pergantian manajemen, pertumbuhan perusahaan, dan kompleksitas perusahaan. Data yang dikaji dalam studi ini terdiri atas laporan tahunan perusahaan yang tercatat pada Bursa Efek Indonesia pada tahun 2014 sampai dengan 2018. Sampel diambil dengan memanfaatkan metode purposive sampling dan yang terpilih sebanyak 439 perusahaan (2.131 data).

Hasil dari studi menyatakan bahwa opini audit dan reputasi KAP memiliki pengaruh signifikan dan positif terhadap pergantian KAP, sedangkan pergantian manajemen mempunyai pengaruh secara negatif pada pergantian Kantor Akuntan Publik. Variabel lainnya yaitu keterlambatan audit, ukuran perusahaan, kesulitan keuangan, pertumbuhan perusahaan, dan kompleksitas perusahaan terbukti tidak memiliki pengaruh secara signifikan terhadap pergantian KAP.
\end{abstract}

Kata Kunci Kantor Akuntan Publik, Pergantian KAP, Rotasi KAP

\section{PENDAHULUAN}

Setiap perseroan memiliki laporan finansial yang dibuat sebagai perwujudan tanggung jawab sekaligus sebagai tolak ukur untuk mengukur kinerja dan performa perusahaan. Sebuah laporan keuangan memiliki tujuan untuk memberikan dan menyediakan informasi finansial perusahaan yang ditujukan kepada pihak yang menggunakan laporan keuangan dalam hal penentuan keputusan ekonomi seperti investasi (Malekinejad, 2016). Mengingat pentingnya laporan keuangan, perusahaan berkewajiban melakukan audit untuk mencegah adanya ketidakwajaran laporan keuangan serta untuk mempertahankan kredibilitas (credibility) dan kehandalan (reliability) laporan keuangan. Pekerjaan audit dilakukan oleh seorang auditor yang memenuhi etika profesi dan bersikap independen yang bekerja di bawah naungan KAP (Kantor Akuntan Publik). 
Seiring dengan bertambahnya perusahaan di Indonesia, peran akuntan publik menjadi sangat penting dan telah menjadi suatu kebutuhan. Semakin meningkat jasa audit dibutuhkan, semakin bertambah pula kuantitas kantor akuntan publik. Susan dan Trisnawati (2011) menyatakan jumlah KAP yang bertambah akan menyebabkan adanya persaingan dan tidak menutup kemungkinan seorang klien atau perusahaan untuk melakukan pergantian KAP. Peristiwa pergantian KAP bersifat tidak informatif. Pergantian KAP yang tidak pernah diungkapkan alasannya seringkali menimbulkan pertanyaan apakah disebabkan oleh pengunduran diri atau pemberhentian dari klien, sehingga perlu dilakukan penelitian lebih lanjut mengingat pentingnya peranan KAP dalam memeriksa kewajaran laporan keuangan (Nazri, Smith, \& Ismail, 2012). Pada penelitian Woo dan Koh (2001) menyatakan bahwa pada umumnya perihal pergantian KAP tidak perlu diungkapkan dalam laporan keuangan tahunan.

\section{LANDASAN TEORI}

Pergantian KAP merupakan suatu kebijakan yang dijalankan oleh suatu perusahaan (Wijayani \& Januarti, 2011). Pemerintahan negara Indonesia menerapkan kebijakan pergantian KAP sesuai dengan pasal 11 Peraturan Pemerintah Nomor 20 Tahun 2015 tentang Praktik Akuntan Publik yang berisikan pernyataan bahwa jasa audit yang diberikan oleh akuntan publik kepada suatu entitas diberi batasan maksimal lima tahun buku secara berurutan dan dapat diberikan kembali setelah dua tahun buku berurutan tidak memberikan jasa tersebut kepada entitas yang bersangkutan.

Alasan mengapa suatu perusahaan melakukan pergantian KAP sampai saat ini benar-benar hanya diketahui oleh pihak perusahaan dan juga tidak pernah dilampirkan ke dalam catatan laporan keuangan tahunan perusahaan. Beberapa alasan utama klien melakukan pergantian KAP diungkapkan dalam beberapa penelitian terdahulu, di antaranya adalah untuk mengurangi biaya audit (Deangelo, 1981), untuk menurunkan biaya agensi (Johnson \& Lys, 1990), untuk memperoleh opini audit yang diharapkan perusahaan (Iskandar \& Wafa, 1993), untuk menyelesaikan perselisihan antara klienauditor (Beattie \& Fearnley, 1995) dan lain-lain.

Opini audit berupa sebuah pernyataan berisikan kewajaran atau ketidakwajaran atas pemeriksaan laporan finansial yang diberikan oleh seorang auditor (Putra, 2014). Setiap perseroan mengharapkan bahwa setiap audit yang dilaksanakan auditor membuahkan hasil berupa unqualified opinion. Jika audit menunjukkan hasil yang tidak diinginkan, perusahaan cenderung menjadikannya sebuah alasan untuk mengganti auditor (Wayan \& Ketut, 2013). Opini audit dinyatakan mempunyai pengaruh signifikan dan positif terhadap pergantian KAP diperoleh oleh Gharibi dan Geraeely (2016).Hasil signifikan negatif kemudian ditemukan oleh Pradita dan Laksito (2015), sedangkan Wea dan Murdiawati (2015) mengungkapkan bahwa opini audit tidak memiliki pengaruh pada pergantian KAP.

Keterlambatan audit adalah rentang waktu yang digunakan oleh auditor untuk mengaudit laporan finansial klien dimulai dari ketika perusahaan melakukan tutup buku. Proses audit dapat memerlukan waktu yang panjang dikarenakan kompleksitas audit yang dilakukan auditor sehingga mengakibatkan terjadinya keterlambatan audit. Azubike \& Anggreh (2014) mengatakan bahwa apabila ketepatan waktu pelaporan keuangan melebihi batas waktu yang ditetapkan maka nilai manfaat dari laporan keuangan akan menurun dan menimbulkan isu-isu dan dampak negatif pada reputasi dan citra suatu 
perusahaan. Semakin lama dan terlambat laporan keuangan dipublikasikan ke pasar modal, semakin tinggi tingkat pergantian KAP.

Keterlambatan audit memiliki pengaruh secara signifikan dan positif pada pergantian KAP dibuktikan oleh Ruroh (2016) dan Arisudhana (2017), sebaliknya hasil signifikan negatif dibuktikan oleh Robbitasari dan Wiratmaja (2013), sedangkan tidak adanya pengaruh antara keterlambatan audit dan pergantian KAP ditemukan dalam penelitian Farid dan Pamudji (2014).

Reputasi KAP ditentukan berdasarkan skala besar atau kecilnya KAP. Reputasi KAP yang tinggi menjadikan perusahaan enggan untuk mengganti KAPnya. Dengan diaudit oleh KAP yang lebih dikenal atau bereputasi baik akan menghasilkan audit dengan kualitas tinggi dan bereputasi tinggi di lingkungan bisnis (Deangelo, 1981). Perusahaan yang menggunakan KAP bereputasi rendah cenderung berpindah ke KAP bereputasi tinggi (Weiner, 2012).

Reputasi KAP dinyatakan berpengaruh secara signifikan dan positif pada pergantian KAP diperoleh oleh Gunady dan Mangoting (2013) dan Sidhi dan Wirakusuma (2015). Sebaliknya, hasil penelitian Prastitis (2012) menghasilkan dampak signifikan negatif, akan tetapi Arifah (2018) dalam penelitiannya membuktikan bahwa reputasi KAP sama sekali tidak mempengaruhi pergantian KAP.

Ukuran perusahaan yang meningkat memberi pertanda bahwa perusahaan tersebut mempunyai tingkat kompleksitas cukup tinggi (Woo \& Koh, 2001). Ukuran perusahaan yang besar mengindikasikan bahwa aset yang dimiliki juga besar/ Wea dan Murdiawati (2015) menyatakan bahwa perusahaan berukuran besar cenderung memiliki kemungkinan yang kecil untuk melakukan pergantian KAP dengan alasan bahwa mayoritas perusahaan besar sudah diaudit oleh KAP besar yaitu Big 4. Dengan demikian, kemungkinan terjadinya pergantian KAP sangat kecil.

Carcello dan Neal (2003) menyatakan bahwa pergantian KAP yang terjadi sebelum jangka waktu perikatan yang ditentukan akan menimbulkan kecurigaan dan tanda tanya dari analisis dan pakar keuangan terhadap perusahaan, sehingga perusahaan berskala besar akan lebih jarang melakukan pergantian KAP apabila dibandingkan dengan perusahaan skala kecil. Pengaruh signifikan negatif berhasil dibuktikan oleh Arifati et al. (2016).. Namun peneliti lainnya membuktikan hasil yang bertentangan seperti Gharibi dan Geraeely (2016) menyatakan pembuktian bahwa hubungan signifikan dan positif terjadi antara ukuran perusahaan pada pergantian KAP. Penelitian dari Chadegani et al. (2011) mengemukakan bahwa tidak ditemukannya pengaruh oleh ukuran perusahaan terhadap pergantian KAP.

Kesulitan keuangan merupakan situasi dimana proporsi utang lebih besar dibandingkan proporsi aset yang dimiliki perusahaan. Perusahaan yang sedang menghadapi financial distress akan berupaya mencari solusi untuk berpindah ke KAP berindependensi tinggi untuk menjaga dan mempertahankan kepercayaan para investor (Fitriani \& Zulaikha, 2014). Dengan melakukan pergantian KAP, perusahaan dapat menghemat biaya audit (Hudaib \& Cooke, 2005).

Hasil penelitian mengenai financial distress berpengaruh secara signifikan dan positif pada pergantian KAP diperoleh dan dibuktikan oleh beberapa penliti yaitu Chen, Chang, dan Yen (2005) dan Nurcahyani (2013), sedangkan hasil penelitian dari Manto dan Manda (2018) menemukan adanya pengaruh signifikan negatif antara kesulitan keuangan dan pergantian KAP. Peneliti lainnya juga menemukan bahwa kesulitan 
keuangan tidak mempengaruhi pergantian KAP secara signifikan, di antaranya Prasetyaningrum (2015).

Pergantian manajemen merupakan perubahan atau pergantian anggota sebuah organisasi yang timbul atas kemauan diri sendiri untuk mengundurkan diri maupun keputusan RUPS (Rapat Umum Pemegang Saham). Manajemen yang mengalami pergantian memungkinkan perusahaan untuk melakukan perubahan kebijakan perusahaan hingga pergantian Kantor Akuntan Publik (Wea \& Murdiawati, 2015). Penelitian Chadegani et al. (2011) mengungkapkan bahwa suatu manajemen dinyatakan terdapat pergantian dengan diindikasikan oleh adanya perubahan direktur perusahaan. Manajemen yang mengalami perubahan akan berganti ke KAP lain yang sependapat dalam hal ide maupun pemikiran, serta penerapan kebijakan akuntansi yang mereka inginkan untuk perusahaan (Nagy, 2005).

Nazri et al. (2012) dan AlAzhar L (2015) menemukan adanya bukti yang menyatakan pergantian manajemen berdampak signifikan dengan arah yang positif pada pergantian KAP. Khasharmeh (2015) menyatakan sebaliknya bahwa ditemukannya pengaruh signifikan dan negatif dari pergantian manajemen terhadap pergantian KAP. Ratnawati (2018) membuktikan bahwa tidak ditemukannya pengaruh antara pergantian manajemen pada pergantian KAP secara signifikan.

Pertumbuhan perusahaan diukur dari nilai penjualan perusahaan. Semakin meningkat penjualan mengindikasikan semakin berkembang perusahaan (Utami, 2015). Perusahaan dengan angka growth yang tinggi cenderung berusaha untuk mempertahankan kondisi dan menyeimbangkan situasi agar tidak jatuh dan tetap mampu menghadapi persaingan yang sangat ketat. Pertumbuhan yang tinggi juga menyebabkan meningkatnya pemisahan antara manajemen dan pemilik. Perusahaan akan menekan biaya agensi dengan mengganti KAP ke KAP berskala besar dengan tujuan menumbuhkan reputasi perusahaan dan meningkatkan kredibilitas laporan keuangan (Niandari, 2014).

Peneliti Joher et al. (2000) yang mengatakan bahwa pertumbuhan perusahaan yang cepat namun tidak didampingi oleh auditor yang ahli dapat menjadi pertimbangan perusahaan untuk mengganti KAP karena manajemen menuntut auditor yang ahli dan berkualitas. Woo dan Koh (2001) membuktikan hasil signifikan positif diikuti dengan penelitian Nazri et al. (2012). Sedangkan hasil signifikan negatif dibuktikan dalam penelitian Fitriani dan Zulaikha (2014). Arifati et al. (2016) mengungkapkan bahwa tidak adanya pengaruh signifikan antara pertumbuhan perusahaan pada pergantian KAP.

Kompleksitas perusahaan merupakan hal yang dipertimbangkan oleh auditor saat sebelum pemeriksaan dilakukan. Cristansy dan Ardiati (2016) menyatakan semakin besar perusahaan, semakin banyak anak perusahan yang dimiliki. Banyaknya anak perusahaan dapat menyebabkan kompleksitas perusahaan menjadi tinggi. Tingginya kompleksitas perusahaan menyebabkan meningkatnya risiko hilangnya pengendalian dan mengakibatkan perusahaan memutuskan untuk melakukan pergantian KAP. Blouin, Grein, dan Rountree (2007) membuktikan bahwa kompleksitas perusahaan berpengaruh signifikan dan terbukti positif pada pergantian KAP. Pembuktian ini selaras dan didukung oleh Fitriani dan Zulaikha (2014) namun disanggah oleh Handini (2017) yang membuktikan bahwa variabel kompleksitas perusahaan sama sekali tidak memiliki pengaruh pada pergantian KAP. 


\section{Perumusan Hipotesis}

$\mathrm{H}_{1}$ : Opini audit berdampak signifikan positif terhadap pergantian KAP.

$\mathrm{H}_{2}$ : Keterlambatan audit berdampak signifikan positif terhadap pergantian KAP.

$\mathrm{H}_{3}$ : $\quad$ Reputasi KAP berdampak signifikan positif terhadap pergantian KAP.

$\mathrm{H}_{4}$ : Ukuran perusahaan berpengaruh signifikan negatif terhadap pergantian KAP.

$\mathrm{H}_{5}$ : $\quad$ Kesulitan keuangan berpengaruh signifikan positif terhadap pergantian KAP.

$\mathrm{H}_{6}$ : Pergantian manajemen berpengaruh signifikan positif terhadap pergantian KAP.

$\mathrm{H}_{7}$ : Pertumbuhan perusahaan berpengaruh signifikan positif terhadap pergantian KAP.

$\mathrm{H}_{8}$ : Kompleksitas perusahaan berpengaruh signifikan positif terhadap pergantian KAP

\section{METODOLOGI PENELITIAN}

Objek yang digunakan terdiri atas perusahaan yang tercatat di dalam Bursa Efek Indonesia (BEI) terhitung dari tahun 2014 hingga 2018. Informasi yang digunakan adalah laporan finansial tahunan perseroan. Pengambilan sampel memanfaatkan metode purposive sampling dengan mengacu pada kriteria-kriteria penelitian seperti di bawah ini.

1. Merupakan perusahaan yang tercatat di Bursa Efek Indonesia (BEI).

2. Memiliki laporan keuangan yang dipublikasikan lima tahun berurutan dari tahun 2014-2018.

3. Menyajikan data untuk pengukuran variabel independen yaitu opini audit, keterlambatan audit, reputasi KAP, ukuran perusahaan, kesulitan keuangan, pergantian manajemen, pertumbuhan perusahaan, dan kompleksitas perusahaan.

4. Perusahaan melakukan tutup buku dengan konsisten yakni pada tanggal 31 bulan Desember setiap periodenya

Berikut di bawah ini merupakan pengukuran variabel dependen dan independen yang digunakan dalam penelitian ini:

\section{Pergantian KAP}

Pergantian KAP memiliki maksud bahwa suatu perusahaan melakukan peralihan dari sebuah KAP ke KAP lainnya. Pergantian KAP dapat diukur dengan dummy variable sebagai berikut.

Pergantian KAP =Nilai 1 (satu) apabila perusahaan mengganti KAP.

Pergantian KAP =Nilai 0 (nol) apabila perusahaan tidak mengganti KAP. Sumber: Nazri et al. (2012).

\section{Opini Audit}

Opini audit ialah pernyataan yang disampaikan oleh KAP kepada klien berupa pendapat yang berisikan kewajaran atas pemeriksaaan laporan keuangan perseroan. Wijayani dan Januarti (2011) menyatakan skala pengukuran opini audit adalah sebagai berikut.

$$
\begin{array}{ll}
\text { Opini Audit }= & \text { Nilai } 1 \text { (satu) jika perusahaan diberi pendapat audit selain } \\
\text { Wajar tanpa pengecualian. }
\end{array}
$$

Sumber: Wijayani dan Januarti (2011). 


\section{Keterlambatan Audit}

Pengukuran variabel independen keterlambatan audit adalah dengan menghitung atau membandingkan tanggal tutup buku perusahaan dan tanggal auditor melakukan audit atas laporan keuangan perseroan.

Sumber: Farid dan Pamudji (2014).

\section{Reputasi KAP}

Chadegani et al. (2011) mengemukakan bahwa kualitas hasil audit ditentukan berdasarkan siapa yang melakukan pemeriksaan/audit. Dalam penelitiannya juga mencantumkan pengukuran untuk reputasi KAP yaitu sebagai berikut.

Reputasi KAP = Nilai 1 (satu) jika klien diaudit oleh Big 4.

Reputasi KAP = Nilai 0 (nol) jika klien diaudit oleh bukan Big 4. Sumber: Chadegani et al. (2011).

\section{Ukuran Perusahaan}

Ukuran perusahaan merupakan pembagian perusahaan ke dalam kelompok tertentu berdasarkan ukurannya, yaitu perusahaan berukuran besar, sedang, dan kecil. Apabila proporsi aset perusahaan semakin besar, hal ini mencerminkan bahwa ukuran perusahaan tersebut juga besar. Untuk mengukur ukuran perusahaan terdapat sebuah skala yang didasarkan pada total aset suatu perusahaan (Edy \& Herawaty, 2005). Ukuran perusahaan diproksikan dengan:

Sumber: Edy dan Herawaty (2005).

Ukuran Perusahaan $=\log$ Asset

\section{Kesulitan Keuangan}

Khasanah dan Nahumury (2013) menyatakan pengukuran financial distress adalah Debt to Equity Ratio (DER). DER yang kian meningkat mengindikasikan jumlah utang perusahaan semakin besar daripada jumlah ekuitas sehingga menimbulkan semakin tinggi beban perusahaan terhadap kreditur.

$$
\text { Rasio Solvabilitas }=\frac{\text { Total Liabilitas }}{\text { Total Ekuitas }}
$$

Sumber : Khasanah dan Nahumury (2013).

\section{Pergantian Manajemen}

Pergantian manajemen diindikasi dengan adanya pergantian posisi direktur utama yang dilakukan oleh sebuah perusahaan (Wea \& Murdiawati, 2015). Dalam penelitian Augustyvena (2017), pergantian manajemen dirumuskan dengan dummy variable; nilai 1 diberikan jika klien melakukan pergantian presiden direktur dalam manajemen dan nilai 0 diberikan jika klien tidak melakukan pergantian presiden direktur dalam manajemen. Sumber: Augustyvena (2017). 


\section{Pertumbuhan Perusahaan}

Pertumbuhan perusahaan dinyatakan dengan angka penjualan perusahaan pada tahun tertentu. Pertumbuhan perusahaan diukur dengan pengukuran di bawah ini.

$$
\text { Pertumbuhan Perusahaan }=\frac{\text { Penjualan } \mathrm{t}-\text { Penjualan } \mathrm{t}-1}{\text { Penjualan } \mathrm{t}-1}
$$

Sumber: Arifah (2018).

\section{Kompleksitas Perusahaan}

Kompleksitas perusahaan diukur dengan jumlah subsidiary yang dimiliki perusahaan (Nazri et al., 2012). Kompleksitas perusahaan dirumuskan dengan dummy variable; nilai 1 jika perusahaan klien memiliki lebih dari 5 (lima) anak perusahaan dan nilai 0 jika perusahaan klien memiliki kurang dari 5 (lima) anak perusahaan.

Sumber: Nazri et al. (2012).

\section{HASIL PENELITIAN}

Tabel 1

Hasil Uji Statistika Deskriptif pada Variabel Skala Rasio

\begin{tabular}{lccccc}
\hline \multicolumn{1}{c}{ Variabel } & N & Minimum & $\begin{array}{c}\text { Maksimu } \\
\text { m }\end{array}$ & Rata-rata & $\begin{array}{c}\text { Std. } \\
\text { Deviasi }\end{array}$ \\
\hline Keterlambatan Audit & 2131 & 7 & 149 & 75.8 & 17.815 \\
Kesulitan Keuangan & 2131 & -30.63853097 & 94.09943013 & 1.867362389 & 3.882363941 \\
Ukuran Perusahaan & 2131 & 10.17900571 & 14.94370534 & 12.53504449 & 0.784670773 \\
Pertumbuhan Perusahaan & 2131 & -3.038288763 & 5.947206221 & 0.106054919 & 0.507056317 \\
\hline
\end{tabular}

Sumber: Data sekunder diolah (2019).

Tabel 2

Hasil Uji Statistika Deskriptif pada Variabel Skala Dummy

\begin{tabular}{clcc}
\hline \multicolumn{1}{c}{ Variabel } & \multicolumn{1}{c}{ Kategori } & Frekuensi & Persentase \\
\hline Pergantian KAP & $\begin{array}{l}\text { 1 = Melakukan pergantian KAP } \\
\text { 0 = Tidak melakukan pergantian }\end{array}$ & 340 & $16.00 \%$ \\
& KAP & 1791 & $84.00 \%$ \\
Opini Auditor & $\begin{array}{l}1=\text { Menerima opini selain wajar } \\
\text { tanpa pengecualian }\end{array}$ & 988 & $46.40 \%$
\end{tabular}




\begin{tabular}{|c|c|c|c|}
\hline & $\begin{array}{l}0=\text { Menerima opini wajar tanpa } \\
\text { pengecualian }\end{array}$ & 1143 & $53.60 \%$ \\
\hline \multirow[t]{2}{*}{ Reputasi KAP } & $1=$ Diaudit oleh Big 4 & 872 & $40.90 \%$ \\
\hline & $0=$ Tidak diaudit oleh Big 4 & 1259 & $59.10 \%$ \\
\hline \multirow[t]{2}{*}{$\begin{array}{l}\text { Pergantian } \\
\text { Manajemen }\end{array}$} & $\begin{array}{l}1=\text { Melakukan pergantian } \\
\text { presiden direktur }\end{array}$ & 305 & $14.30 \%$ \\
\hline & $\begin{array}{l}0=\text { Tidak melakukan pergantian } \\
\text { presiden direktur }\end{array}$ & 1826 & $85.70 \%$ \\
\hline \multirow[t]{2}{*}{$\begin{array}{l}\text { Kompleksitas } \\
\text { Perusahaan }\end{array}$} & $\begin{array}{l}1=\text { Jumlah anak perusahaan lebih } \\
\text { dari } 5\end{array}$ & 839 & $39.40 \%$ \\
\hline & $\begin{array}{l}0=\text { Jumlah anak perusahaan } \\
\text { kurang dari } 5\end{array}$ & 1292 & $60.60 \%$ \\
\hline
\end{tabular}

Sumber: Data sekunder diolah (2019).

Tabel 1 memuat kolom $\mathrm{N}$ yang melambangkan jumlah data yang diobservasi yaitu 2.131 data. Tabel di atas menunjukkan bahwa waktu yang diperlukan oleh auditor minimal adalah 7 hari, maksimal 149 hari serta rata-rata membutuhkan 75 hari atau kurang dari 4 bulan. Hal ini didukung dengan batas ketepatan waktu penyampaian laporan keuangan yang dicantumkan dalam Peraturan Otoritas Jasa Keuangan Nomor 29/POJK.04/2016. Keputusan tersebut menjelaskan bahwa batas penyampaian laporan finansial yang telah diaudit adalah paling lambat 4 (empat) bulan terhitung dari tanggal perusahaan melakukan tutup buku.

Tingkat financial distress perusahaan di Indonesia adalah $-30 \%$ hingga $94 \%$ dengan rata-rata $1 \%$. Nilai $-30 \%$ mencerminkan bahwa perusahaan mempunyai kondisi finansial yang tidak sehat. Bakrie Sumatera Plantations Tbk merupakan perusahaan yang dimaksud. Nilai liabilitas dan ekuitas yang dimiliki pada tahun 2017 berturut-turut adalah Rp14.352.436.000.000,00 dan -Rp468.444.000.000,00. Pada tahun 2016 terjadi penurunan ekuitas sebesar Rp729.245.000.000.00.

PT. Akbar Indomakmur Stimec dengan total aset terendah sejumlah Rp15.101.000.000,00 sedangkan PT. Bank Rakyat Indonesia (Persero) Tbk memegang total aset tertinggi sejumlah Rp878.426.312.000.000,00. Peraturan Otoritas Jasa Keuangan (OJK) Nomor 54/POJK.04/2017 menjelaskan bahwa emiten yang tergolong skala menengah memiliki jumlah aset antara Rp50.000.000.000,00 (lima puluh miliar rupiah) hingga Rp250.000.000.000,00 (dua ratus lima puluh miliar rupiah). Tabel 4.2 menunjukkan rata-rata perusahaan mempunyai total aset sejumlah Rp3.357.359.000.000,00 yang menandakan bahwa perusahaan yang tercatat di BEI termasuk perusahaan berskala besar. Tingkat pertumbuhan perusahaan di BEI memiliki minimum pertumbuhan penjualan perusahaan sebesar $-303,8 \%$, maksimum $594,7 \%$, dan rata-rata $10,6 \%$. Perusahaan yang mengalami penurunan penjualan sangat signifikan adalah PT. Saratoga Investama Sedaya Tbk yang bergerak di bidang usaha investasi.

Diketahui pada Tabel 2 bahwa perusahaan yang melakukan pergantian KAP adalah sebesar $16 \%$ dari seluruh data yang diobservasi. Kesimpulan yang diperoleh 
adalah perusahaan yang tercatat di BEI cenderung jarang melakukan pergantian KAP. Hal ini mencerminkan bahwa perusahaan Indonesia umumnya telah memenuhi kebijakan Peraturan Pemerintah Republik Indonesia Nomor 20 Tahun 2015 tentang Praktik Akuntan Publik yaitu menggunakan jasa profesional KAP yang sama maksimal 5 tahun buku secara berurutan. Perusahaan yang yang diaudit oleh Big 4 sebanyak 40,90\%, sedangkan yang diaudit oleh Non-Big 4 adalah sebanyak 59,10\%. Akumulasi persentase tersebut dapat diinterpretasikan bahwa mayoritas perusahaan di Bursa Efek Indonesia masih cenderung memanfaatkan KAP Non-Big 4.

Interpretasi untuk variabel opini audit, perusahaan cenderung menerima opini wajar tanpa pengecualian dengan persentase sebesar 53,60\%, sehingga memberikan indikasi bahwa mayoritas dari laporan finansial perusahaan yang tercatat di BEI berkualitas cukup baik sehingga memenuhi kriteria wajar tanpa pengecualian, sedangkan interpretasi untuk variabel tingkat pergantian manajemen, perusahaan di Bursa Efek Indonesia cenderung tidak melakukan pergantian presiden direktur yaitu sebesar $85,70 \%$. Sedangkan untuk tingkat kompleksitas perusahaan, mayoritas perusahaan mempunyai anak perusahaan kurang dari 5 (lima) yaitu sebesar 60,60\%.

Tabel 3

\section{Hasil Uji Wald}

\begin{tabular}{lcccc}
\hline \multicolumn{1}{c}{ Variabel } & $\begin{array}{c}\text { Unstandardized } \\
\text { Coefficients }(\boldsymbol{B})\end{array}$ & Sig & Kesimpulan & Keterangan \\
\hline Konstan & -2.265 & 0.119 & - & - \\
Opini Audit & 1.754 & 0.000 & Signifikan Positif & Terbukti \\
Keterlambatan Audit & -0.006 & 0.137 & Tidak Signifikan & Tidak Terbukti \\
Reputasi KAP & 1.074 & 0.000 & Signifikan Positif & Terbukti \\
Ukuran Perusahaan & -0.045 & 0.655 & Tidak Signifikan & Tidak Terbukti \\
Kesulitan Keuangan & 0.015 & 0.347 & Tidak Signifikan & Tidak Terbukti \\
Pergantian Manajemen & -0.506 & 0.002 & Signifikan Negatif & Tidak Terbukti \\
Kompleksitas Perusahaan & 0.234 & 0.110 & Tidak Signifikan & Tidak Terbukti \\
Pertumbuhan Perusahaan & -0.037 & 0.745 & Tidak Signifikan & Tidak Terbukti \\
\hline Suman
\end{tabular}

Sumber: Data sekunder diolah (2019).

Tabel di atas memuat hasil uji bahwa opini audit mempunyai tingkat signifikansi 0,000 kurang dari 0,05 diikuti dengan nilai koefisien 1.754 sehingga dinyatakan berpengaruh positif pada pergantian KAP. Pengaruh ini mengindikasikan bahwa perusahaan yang memperoleh pendapat audit selain pendapat wajar tanpa pengecualian cenderung akan melakukan pergantian KAP. Gunady dan Mangoting (2013) menyatakan bahwa pendapat audit yang diharapkan oleh perusahaan ialah unqualified opinion. Opini audit dapat mempengaruhi pandangan investor dan kreditor dalam mengambil keputusan karena opini audit dapat mencerminkan kondisi dan situasi perusahaan entitas.

Berlandaskan hasil uji Wald pada Tabel 3, tingkat signifikansi keterlambatan audit adalah 0,137 yang melebihi 0,05. Nilai ini menginterpretasikan bahwa keterlambatan audit tidak membawa pengaruh yang signifikan pada pergantian KAP. Ketepatan waktu dapat memberi pengaruh kepada pengguna laporan keuangan dalam menentukan keputusan sehingga lamanya proses audit oleh auditor dianggap penting (Carslaw \& Kaplan, 1991). Jika auditor gagal dalam memenuhi ketepatan waktu pelaporan 
keuangannya, perusahaan cenderung akan mengambil tindakan untuk melakukan pergantian KAP. Namun hal ini tidak selalu terjadi. Apabila auditor dapat menyelesaikan proses auditnya dalam rentang waktu paling lambat 4 (empat) bulan setelah tanggal tutup buku perusahaan dengan berdasar kepada Peraturan Otoritas Jasa Keuangan Nomor 29/POJK.04/2016, maka ini akan menjadi poin yang dapat dipertimbangkan oleh perusahaan untuk tidak melakukan pergantian KAP. Memilih untuk mengganti ke KAP yang baru juga bukan merupakan alternatif yang baik karena tidak menutup kemungkinan atau resiko bahwa KAP yang baru lebih memahami dan lebih cepat untuk mengaudit laporan finansial perusahaan.

Dalam Tabel 3 memperlihatkan tingkat signifikansi variabel reputasi KAP sebesar 0,000 yaitu kurang dari 0,05 dan nilai koefisien 1,074 sehingga reputasi KAP dinyatakan berpengaruh secara signifikan dan positif pada pergantian KAP. Siegel, NaserTavakolian, dan O'Shaughnessy (2008) mengatakan bahwa perusahaan dapat memutuskan untuk mempertahankan atau memberhentikan suatu KAP dengan alasan reputasinya. Penelitian Sidhi dan Wirakusuma (2015) menyatakan bahwa apabila sebuah perseroan diaudit oleh KAP bereputasi tinggi atau Big 4, maka perusahaan tersebut cenderung tidak akan menggantinya. Sedangkan perusahaan yang menggunakan jasa KAP bereputasi rendah atau Non-Big 4 memiliki probabilitas yang besar untuk upgrade ke KAP bereputasi tinggi dengan alasan perusahaan mengharapkan Kantor Akuntan Publik yang dapat memberikan serta menyediakan jasa profesional sesuai dengan apa yang dibutuhkan perusahaan. Contohnya dalam hal penyampaian opini audit.

Interpretasi yang dapat dijelaskan berdasarkan Tabel 3 adalah ukuran perusahaan tidak berpengaruh pada pergantian KAP dengan nilai signifikansi 0,655 melebihi 0,05. Sidhi dan Wirakusuma (2015) dalam penelitiannya mengutarakan bahwa perusahaan berskala besar cenderung tetap menggunakan jasa KAP Big 4, sedangkan perusahaan dengan jumlah aset yang kecil akan cenderung menggunakan jasa KAP Non-Big 4. KAP kecil akan mengalami kesulitan dalam melaksanakan audit perusahaan klien apabila perusahaan tersebut berskala besar. KAP besar cenderung mengalami penurunan reputasi apabila menerima perusahaan berskala kecil sebagai klien auditnya. Pernyataan ini juga didukung oleh Yanti (2017). Alasan lain yang mendukung tidak ditemukannya pengaruh antara ukuran perusahaan pada pergantian KAP dikemukakan oleh Utomo (2010). Perusahaan berskala besar cenderung tidak mengganti KAPnya. KAP yang sekarang dinilai lebih mampu dan telah memahami keadaan perusahaan.

Hasil uji Wald pada Tabel 3 menerangkan tingkat signifikansi 0,347 dan melebihi 0,05 . Interpretasi yang dapat diambil adalah kesulitan keuangan tidak mempunyai pengaruh secara signifikan pada pergantian KAP. Kesulitan keuangan gagal sebagai determinan yang menyebabkan terjadinya pergantian KAP disebabkan oleh mayoritas dari sampel perusahaan yang diteliti diaudit oleh KAP Non-Big 4. Perusahaan yang tengah menghadapi kesulitan keuangan akan semakin sulit apabila melakukan pergantian KAP Non-Big 4 menuju KAP Big 4. Hal ini dikarenakan adanya kenaikan fee atau biaya jasa audit Damayanti dan Sudarma (2007). Tidak adanya pengaruh antara kesulitan keuangan dan pergantian KAP juga dijelaskan dalam penelitian Meryani dan Mimba (2013). Perusahaan yang sedang sulit dalam keuangan cenderung tidak mengganti KAP untuk menjaga dan mempertahankan kepercayaan investor, karena pergantian KAP dapat menimbulkan anggapan yang negatif. Melakukan pergantian KAP juga tidak selalu menjadi solusi yang baik karena adanya kekhawatiran bahwa KAP yang baru dapat 
menghasilkan hasil audit yang tidak diharapkan oleh perusahaan (Farid dan Pamudji, 2014).

Interpretasi yang dapat diambil dari Tabel 3 adalah pergantian manajemen terbukti memberikan pengaruh yang signifikan dan negatif pada pergantian KAP dengan nilai signifikansi 0,002 kurang dari 0,05 serta nilai koefisien sebesar -0,0506. Hal ini dapat memberikan interpretasi bahwa perusahaan yang tidak mengganti presiden direktur cenderung mengganti KAP. Peristiwa ini dapat disebabkan oleh pimpinan perusahaan telah menaati Peraturan Pemerintah Republik Indonesia Nomor 20 Tahun 2015 yang mewajibkan untuk melakukan pergantian KAP setiap 5 tahun sekali apabila diaudit oleh KAP yang sama berturut-turut.

Dalam Tabel 3 memperlihatkan bahwa pertumbuhan perusahaan mempunyai tingkat signifikansi 0,745 melebihi 0,05 sehingga pertumbuhan perusahaan dinyatakan tidak memberikan pengaruh yang signifikan pada pergantian KAP. Dalam penelitian yang diteliti oleh Khasanah dan Nahumury (2013) menyebutkan bahwa saat perusahaan mengalami peningkatan penjualan namun tidak diikutsertakan dengan peningkatan aset dan laba maka perusahaan dinilai belum memiliki kemampuan untuk mengganti KAP. Hal ini dapat mengindikasikan bahwa perusahaan sedang mengalami kesulitan dalam finansial. Alasan lainnya yang dapat mendukung tidak adanya pengaruh dari pertumbuhan perjualan terhadap pergantian KAP adalah perusahaan melakukan pertimbangan untuk mempertahankan nama baik atau reputasi perusahaan dengan tetap menggunakan jasa KAP yang sama (Nuryanti, 2012). Dalam penelitian Arifati et al. (2016) mengutarakan bahwa perusahaan yang sedang mengalami pertumbuhan dapat memperoleh perhatian dari publik sehingga segala keputusan yang diambil harus dipertimbangkan dengan sungguh-sungguh. Perusahaan menghindari resiko peningkatan jasa audit apabila melakukan pergantian ke KAP yang baru. Hal ini dilakukan demi menghemat biaya jika pertumbuhan penjualan tidak diiringi dengan peningkatan laba perusahaan.

Tabel 3 menginterpretasikan bahwa kompleksitas perusahaan tidak berpengaruh pada pergantian KAP. Hasil uji Wald menghasilkan nilai signifikansi sebesar 0,110 yang melebihi 0,05. Handini (2017) mengutarakan bahwa perusahaan yang kompleks mempunyai hubungan agensi yang tinggi. Hal ini akan menimbulkan kesulitan pemantauan antara principal dan agent sehingga perusahaan lebih membutuhkan auditor yang independen pula. Alasan ini tidak cukup kuat untuk mendorong perusahaan dalam mengganti KAP karena KAP yang baru belum tentu dapat memahami kondisi perusahaan sebagaimana KAP lama memahaminya.

\section{KESIMPULAN}

Pengkajian ini memiliki tujuan untuk mengidentifikasi pengaruh opini audit, keterlambatan audit, reputasi KAP, ukuran perusahaan, kesulitan keuangan, pergantian manajemen, pertumbuhan perusahaan, dan kompleksitas perusahaan pada pergantian KAP. Pengkajian ini memanfaatkan objek perusahaan-perusahaan yang terdapat dalam BEI. Rentang waktu penelitian adalah tahun 2014-2018.

Analisis dan pengujian data menghasilkan pembuktian bahwa opini audit dan reputasi KAP berpengaruh signifikan dan positif pada pergantian KAP. Pergantian manajemen berpengaruh secara signifikan dan negatif pada pergantian KAP, sedangkan keterlambatan audit, ukuran perusahaan, kesulitan keuangan, pertumbuhan perusahaan serta kompleksitas perusahaan terbukti tidak mempengaruhi terjadinya pergantian KAP. 


\section{UCAPAN TERIMA KASIH}

Penelitian ini dapat dilaksanakan dengan lancar karena bantuan dari berbagai pihak seperti Universitas Internasional Batam (UIB), rekan dosen dan teman-teman yang telah memberikan dukungan dan motivasi dalam penelitian ini.

\section{DAFTAR PUSTAKA}

AlAzhar L. (2015). Influence of financial distress, management turnover and audit opinion to auditor switching. Research Journal of Finance and Accounting Www.Iiste.Org ISSN, 6(24), 120-126.

Arifah, A. H. N. (2018). Analisis pengaruh pergantian manajemen, ukuran kap, opini audit, pertumbuhan perusahaan dan audit delay terhadap auditor switching.

Arifati, R., Andini, R., \& Saidin. (2016). Analysis of effect of audit opinion, kap size, financial trouble, turn management, company size and growth company towards auditor switching. Journal of Accounting, 2(2).

Arisudhana, D. (2017). Pengaruh audit delay, ukuran klien, opini audit tahun sebelumnya, reputasi kap dan return in asset terhadap pergantian auditor sukarela. Jurnal Akuntansi Dan Keuangan, 6(1). https://doi.org/ISSN: 22527141

Augustyvena, E. V. (2017). Pengaruh pergantian manajemen, opini audit dan kesulitan keuangan perusahaan terhadap pergantian auditor.

Azubike, J. U. ., \& Anggreh, M. (2014). Corporate governance and audit delay in Nigerian quoted companies. European Journal of Accounting, Auditing and Finance Research, 2(10), 22-33.

Beattie, V., \& Fearnley, S. (1995). The importance of audit firm characteristics and the drivers of auditor change in UK listed companies. Accounting and Business Research, 25(100), 227-239. https://doi.org/10.1080/00014788.1995.9729912

Blouin, J., Grein, B. M., \& Rountree, B. R. (2007). An analysis of forced auditor change: The case of former Arthur Andersen clients. Accounting Review, 82(3), 621-650. https://doi.org/10.2308/accr.2007.82.3.621

Carcello, J. V, \& Neal, T. L. (2003). Audit committee independence and disclosure : choice for financially distressed firms. Corporate Governance, 11(4), 289-299. https://doi.org/10.1111/1467-8683.00327

Carslaw, C. A. P. N., \& Kaplan, S. E. (1991). An examination of audit delay: further evidence from New Zealand. Accounting and Business Research, 22(85), 21-32. https://doi.org/10.1080/00014788.1991.9729414 
Chadegani, A. A., Mohamed, Z. M., \& Jari, A. (2011). The determinant factors of auditor switch among companies listed on Tehran Stock Exchange. International Research Journal of Finance and Economics, 80(80), 158-168. https://doi.org/10.1167/iovs.117524

Chen, C., Chang, F.-H., \& Yen, G. (2005). The information contents of auditor change in financial distress prediction, 1-30.

Cristansy, J., \& Ardiati, A. Y. (2016). Pengaruh kompleksitas perusahaan, ukuran perusahaan dan ukuran kap terhadap fee audit. MODUS, 30(2), 198-211.

Damayanti, S., \& Sudarma, M. (2007). Faktor-faktor yang mempengaruhi perusahaan berpindah kantor akuntan publik, 1-23.

Deangelo, L. E. (1981). Auditor size and audit quality. Journal of Accounting and Economics, 3(July), 183-199.

Edy, S., \& Herawaty, A. (2005). Analisis pengaruh karakteristik perusahaan terhadap tindakan perataan laba. Simposium Nasional Akuntansi, (September), 15-16.

Farid, Z., \& Pamudji, S. (2014). Faktor-faktor yang mempengaruhi pergantian kantor akuntan publik pada perusahaan go public di Indonesia. Diponegoro Journal of Accounting, 3(4).

Fitriani, N. A., \& Zulaikha. (2014). Analisis faktor-faktor yang mempengaruhi voluntary auditor switching di perusahaan manufaktur Indonesia. Diponegoro Journal of Accounting, 3, 1-13.

Gharibi, A. K., \& Geraeely, M. S. (2016). Investigating the effective factors on changing auditor: Evidences of Iranian firms. Problems and Perspectives in Management, 14(3), 401-406. https://doi.org/10.21511/ppm.14(3-si).2016.14

Gunady, F., \& Mangoting, Y. (2013). Faktor-faktor yang mempengaruhi keputusan perusahaan manufaktur melakukan pergantian kantor akuntan publik. Tax \& Accounting Review, 3(2), 1-13.

Handini, U. Y. M. (2017). Pengaruh audit fee, going concern, financial distress, ukuran perusahaan klien, kepemiikan institusional dan kompleksitas perusahaan terhadap auditor switching.

Hudaib, M., \& Cooke, T. E. (2005). The impact of managing director changes and financial distress on audit qualification and auditor switching. Journal of Business Finance and Accounting, 32(9-10), 1703-1739. https://doi.org/10.1111/\%28ISSN\%291468-5957/issues 
Iskandar, M. T., \& Wafa, M. S. G. W. S. A. (1993). Incidence of qualified opinions and the effects on auditor switchin : An empirical study in Malaysia. Jurnal Pengurusan 12.

Joher, H., Mohamad, S., Ali, M., \& Annuar, M. N. (2000). The auditor switch decision of Malaysian listed firms : An analysis of its determinants \& wealth effect.

Johnson, W. B., \& Lys, T. (1990). The market for audit services. Evidence from voluntary auditor changes. Journal of Accounting and Economics, 12(1-3), 281-308. https://doi.org/10.1016/0165-4101(90)90051-5

Khasanah, I., \& Nahumury, J. (2013). The factors affecting auditor switching in manufacturing companies listed in Indonesia Stock Exchange (BEI). Journal of Accounting, 3(2), 203-212. https://doi.org/10.14414/tiar.13.030210

Khasharmeh, H. A. (2015). Determinants of auditor switching in Bahraini's listed companies - An empirical study. European Journal of Accounting, Auditing and Finance Research, 3(11), 73-99. https://doi.org/10.1017/CBO9781107415324.004

Malekinejad, R. (2016). The effectiveness of financial statements in management decision making. International Journal of Accounting Research, 2(11).

Manto, J. I., \& Manda, D. L. (2018). Pengaruh financial distress, pergantian manajemen dan ukuran kap terhadap auditor switching. Media Riset Akuntansi, Auditing \& Informasi, $18(2), 205-224$.

Meryani, L. H., \& Mimba, N. P. S. H. (2013). Pengaruh financial distress, going concern opinion dan management changes pada voluntary auditor switching. E-Jurnal Akuntansi Universitas Udayana, 629-648.

Nagy, A. L. (2005). Mandatory audit firm turnover, financial reporting quality, and client bargaining power: the case of Arthur Andersen. Accounting Horizons, 19(2), 51-68.

Nazri, S. N. F. S. M., Smith, M., \& Ismail, Z. (2012). Factors influencing auditor change: Evidence from Malaysia. Asian Review of Accounting, 20(3), 222-240. https://doi.org/10.1108/13217341211263274

Niandari, N. (2014). Voluntary auditor switching : Perspektif peraturan menteri keuangan. Jurnal Akuntansi Bisnis, 8.

Nurcahyani, Y. (2013). Pengaruh tingkat pertumbuhan perusahaan, financial distress dan ukuran kap terhadap pergantian auditor.

Nuryanti, L. (2012). Pengaruh opini audit dan tingkat pertumbuhan perusahaan terhadap pergantian auditor.

Peraturan Pemerintah Nomor 20 Tahun 2015 tentang Praktik Akuntan Publik, Pub. L. No. 
20 (2015). Indonesia.

Pradita, S. A. P., \& Laksito, H. (2015). Analisis hubungan auditor-klien : Faktor-faktor yang mempengaruhi auditor switching. Diponegoro Journal of Accounting, 4(4), 1-12. Retrieved from http://ejournal-s1.undip.ac.id/index.php/accounting

Prasetyaningrum, H. (2015). Analisis faktor-faktor yang mempengauhi auditor switching.

Prastitis, Y. T. (2012). Auditor switching : Analisis berdasar ukuran kap, ukuran klien dan financial distress. Accounting Analysis Journal, 1(2), 1-6. https://doi.org/ISSN 22526765

Putra, I. W. D. W. (2014). Pengaruh financial distress, rentabilitas, pertumbuhan perusahaan dan opini audit pada pergantian auditor. E-Jurnal Akuntansi Universitas Udayana, 2(8), 308-323.

Ratnawati, L. F. (2018). Pengaruh management turnover, financial distress, opini audit, ukuran kap dan ukuran perusahaan terhadap auditor switching.

Robbitasari, A. P., \& Wiratmaja, I. dewa N. (2013). Pengaruh opini audit going concern, kepemilikan institusional dan audit delay pada voluntary auditor switching. E-Jurnal Akuntansi Universitas Udayana, 3, 652-665.

Ruroh, F. M. (2016). Pengaruh pergantian manajemen, kesulitan keuangan, ukuran kap dan audit delay terhadap auditor switching. Jurnal Nominal, (3), 68-80.

Sidhi, B. A. D. M., \& Wirakusuma, M. G. (2015). Pengaruh ukuran perusahaan, tingkat penjualan perusahaan dan reputasi kap pada pergantian kap. E-Jurnal Akuntansi Universitas Udayana, 13(3), 723-736.

Siegel, P. H., Naser-Tavakolian, M., \& O’Shaughnessy, J. J. (2008). Factors influencing auditor switching in the European union. Ssrn, (October). https://doi.org/10.2139/ssrn.1612540

Susan, \& Trisnawati, E. (2011). Faktor-faktor yang mempengaruhi perusahaan melakukan auditor switch. Jurnal Bisnis Dan Akuntansi, 13.

Utami, S. F. (2015). Analisis faktor-faktor yang mempengaruhi pergantian auditor secara sukarela. Jom FEKON, 2, 1-15.

Utomo, B. D. (2010). Pengaruh client contracting environment, reputasi klien, dan ukuran kap terhadap pergantian kap pada perusahaan manufaktur yang terdaftar di BEI. Skripsi.

Wayan, N. A. J., \& Ketut, N. R. (2013). Auditor switching dan faktor-faktor yang mempengaruhinya. E-Jurnal Akuntansi Universitas Udayana 3.3, 3, 231-246.

Wea, A. N. S., \& Murdiawati, D. (2015). Faktor-faktor yang mempengaruhi auditor 
switching secara voluntary pada perusahaan manufaktur. Jurnal Bisnis Dan Ekonomi.

Weiner, J. (2012). Auditor size vs auditor quality : An analysis of auditor switches.

Wijayani, E. D., \& Januarti, I. (2011). Analisis faktor-faktor yang mempengaruhi perusahan di Indonesia melakukan auditor switching. Simposium Nasional Akuntansi, $21-22$.

Woo, E. S., \& Koh, H. C. (2001). Factors associated with auditor changes: A Singapore study. Accounting and Business Research, 31(2), 133-144. https://doi.org/10.1080/00014788.2001.9729607

Yanti, N. D. (2017). The effect of audit opinion, financial distress, client size, management turn and kap size on auditor switching. Journal of Economics, Business \& Accountancy Ventura, 20(2), 237-248. https://doi.org/10.14414/jebav.v20i2.1125 